\title{
The Effect of Individual Innovation and Emotional Intelligence on Positive Organizational Behavior
}

\author{
Nuri Berk Güngör (Corresponding author) \\ Faculty of Sports Sciences, Balıkesir University, Balıkesir, Turkey \\ E-mail: nuriberkgungor@gmail.com \\ Zulbiye Kaçay \\ Faculty of Sports Sciences, Çanakkale University, Çanakkale, Turkey \\ E-mail: zzkacay@gmail.com
}

Fikret Soyer

Faculty of Sports Sciences, Balıkesir University, Balıkesir, Turkey

E-mail: fikretsoyer@gmail.com

Received: November 5, 2021 Accepted: December 10, 2021

Published: December 31, 2021

doi:10.5296/jei.v7i3.19267 URL: https://doi.org/10.5296/jei.v7i3.19267

\begin{abstract}
The purpose of this research is to examine the effects of individual innovation and emotional intelligence levels on organizational behavior of the participants working in the Provincial Directorate of Youth and Sports. The study group of the research consists of 77 female (38.7\%) and 122 male (61.3\%) participants working in the Provincial Directorate of Youth and Sports. As a data collection tool in the research; Individual Innovation, Emotional Intelligence and Positive Organizational Behavior Scales were used. The participants drew a high level of innovative profile; It can be stated that he has an above-average level of emotional intelligence and organizational behavior. According to the results of the research; A significant, positive and moderate relationship was found between individual innovation, emotional intelligence and organizational behavior. In addition; It can be said that $53 \%$ of organizational behavior is explained by individual innovation and emotional intelligence characteristics.
\end{abstract}


Keywords: Individual innovation, Emotional intelligence, Organizational behavior

\section{Introduction}

Republic of Turkey Ministry of Youth and Sports, General Directorate of Sports is a socially important organization because it is a structure that appeals to large masses in the society and because of its task in developing sports in the country, spreading it from the grassroots and presenting it to the public (Kaçay \& Soyer, 2020). It is considered important that it works in cooperation with higher education institutions that provide sports education and that it provides opportunities for the employment of people who graduate from these institutions. In addition, it is among the factors that contribute to sports education that it carries out programs for the training of trainers, who are among the stakeholders of sports, and that it targets personnel development through in-service trainings.

Therefore, the survival of an organization in the national and international arena by minimizing the effects of globalization reflected in all areas of society, including sports, will be possible with the diversity that will be revealed by the organization's personnel, which is one of the most prioritized production factors in organizational life (Y1ldiz \& Bostanc1, 2016). When considered from this point of view, the concept of individual innovation comes to the fore.

The concept of innovation can be mentioned as the most important factor that will facilitate adaptation to changes and developments in the organizational environment. In this respect, it can be said that innovation is a premise in adapting to change (Devloo et al., 2014). Innovation is the presentation of ideas that can be useful to the organization and make a difference (Damanpour \& Aravind, 2011). The main purpose here is to reveal the knowledge, skills, abilities and experiences of each individual in order to achieve the foreseen organizational goals (Baysal, 2016). Scott and Bruce (1994) argue that four elements (leader, individual, work group, an innovative organizational climate) must interact in order to reveal individual innovation (Scott \& Bruce, 1994). Hurt, Joseph, and Cook (1977) emphasize that in order to be able to talk about innovation, it is necessary to be enthusiastic about change, development and trying different things. In short, individual innovation refers to the actions of individuals who are open to change and new experiences, who are pioneers in making a difference, and who do not hesitate to take risks in this regard. Being innovative and exhibiting innovative behaviors is possible by activating different types of intelligence. In this context, the contributions of emotional intelligence as a type of intelligence can be mentioned.

Emotional intelligence is a type of intelligence that enables the individual to control himself and his emotions and supports the individual in dealing with problems easily (Mumcuoğlu, 2002). In addition, it can be expressed as a talent that will contribute to the regulation of the relations with the environment and people with which the General Directorate of Sports personnel are in constant communication and interaction, to the management of emotions and to exhibit positive organizational behavior by using their empathic tendencies.

On the other hand, without intelligence, which is defined as the ability to see the similar and 


\section{Ml Macrothink}

different aspects between objects, individuals, actions and emotions, and to analyze their relations with each other while exhibiting behavior (Mayer et al., 2001), it is not possible to talk about effects such as directing any behavior in an individual's life and reaching his goals.

In order for organizations to achieve their goals, it is important to cope with the competitive environment brought by globalization, to adapt to technological developments and changing conditions, in short, to minimize or eliminate the negative effects of these concepts that will affect the continuity of the organization (Y1ldız \& Çiftçi, 2021). Overcoming this situation depends on the personnels' ability of exhibiting the necessary behaviors inside and outside the organization. In this respect, positive organizational behavior, which focuses on the behaviors that can be improved, advanced and managed well rather than the mistakes and faults of the employees (Luthans et al., 2008), gains importance. Among these behaviors there are optimism, hope, self-efficacy and resilience that facilitates coping with problems. In order to achieve organizational success and ensure sustainability by providing competitive advantage, all kinds of variables that can contribute to positive organizational behavior of employees should be investigated and revealed.

In this direction, it was aimed to determine to what extent the individual innovation and emotional intelligence levels of the personnel of the General Directorate of Sports, whose goal and task is to ensure that all individuals who make up the society can benefit from sports activities on equal terms, and who contribute to the creation of a healthy generation in this respect, contribute to the levels of positive organizational behavior.

\section{Method}

\subsection{Research Model}

This research, in which the effect of individual innovation and emotional intelligence level of the participants working in the General Directorate of Youth and Sports, on organizational behavior was examined, was designed in a relational screening model and a descriptive structure. Relational screening model, on the other hand, is a research model that aims to determine the existence and/or degree of change between two or more variables (Karasar, 2013).

\subsection{Research Group}

The study group of the research comprised of 77 females $(38.7 \%)$ and 122 males $(61.3 \%)$ participants working in the General Directorate of Youth and Sports in 2020. In the formation of the study group of the research, the easily accessible sampling method was preferred among the purposeful sampling methods. The mean age of the participants in the study was determined as $37.81 \pm 9.17$.

\subsection{Data Collection Tools}

\subsubsection{Individual Innovation Scale (IS)}

Individual Innovation Scale was developed by Hurt, Joseph, and Cook (1977) and adapted into Turkish by Kılıçer and Odabaş1 (2010). Scale has a 5-point Likert structure and consists 
of 4 sub-dimensions and 20 items in total. These sub-dimensions are; resistance to change, opinion leadership, openness to experience and risk taking. The innovation score is calculated by subtracting the total score obtained from the negative items from the total score obtained from the positive items in the scale and adding 42 points. In total, the lowest 14 points and the highest 94 points can be obtained from the scale. According to the calculated scores, the individual innovation profiles of the participants can be obtained. If the calculated score is above 80 , it is expressed as "Innovative", between 69 and 80 as "Pioneer", between 57 and 68 as "Questionist", between 46 and 56 points "Skeptical" and below 46 points as "Traditional". Also, individuals with a score above 68 are attributed as highly innovative, while individuals with a score below 64 are interpreted as low in innovation. When the original form of the scale is examined, the reliability coefficient is .82. (K1lıçer \& Odabaşı, 2010). The reliability coefficient obtained from the data set is was determined as .79.

\subsubsection{Emotional Intelligence Scale (EI)}

The scale was developed by Chan $(2004,2006)$ and brought to the literature. Consisting of 12 items, the scale also consists of 4 sub-dimensions. The sub-dimensions are; emotional appraisal, empathetic sensitivity, positive emotional management, and positive use of emotions. In the original form of the study, the internal consistency coefficient for the whole scale was .85. The internal consistency coefficient of the data set used in the research was determined as .96 .

\subsubsection{Positive Organizational Behavior Scale (POB)}

The scale was developed by Luthans et al. (2007). Although the total number of items of the scale is 24 , it is structured as 4 sub-dimensions. Sub dimensions; named as "optimism", "psychological resilience", "hope" and "self-efficacy". The internal consistency coefficient in the original form of the scale is .93 , and the internal consistency coefficient obtained from the data set is .95 .

\subsection{Analysis of Data}

While performing the analysis of the data set, first of all, the Shapiro-Wilk test significance results were examined and the skewness and kurtosis values were taken into account in order to determine whether the data set was normally distributed. These values for the measurement tools used in the research are between -1.5 and +1.5 (BYO: $-.25, .56$; DZ: -.60, 1.44; OD: $-.96,1.16)$. The relevant result shows that the data set used in the research meets the normal distribution conditions (Tabachnick \& Fidell, 2013). Pearson Product Moments Correlation Coefficient ( $r$ ) was used to determine the relationship between the variables in the study. Multiple linear regression analysis was applied between individual innovation, emotional intelligence and positive organizational behavior variables. In addition, descriptive statistics were used in order to determine the average scores obtained from the scales. The analyzes used in the research were carried out using SPSS 22 Package Program and Excel Database.

\section{Results}

In this section, the findings obtained as a result of the analysis of the data are given. 


\section{Macrothink}

Table 1. Average scores of participants from Individual Innovation, Emotional Intelligence and Organizational Behavior Scales

\begin{tabular}{|l|l|l|l|l|l|}
\hline Scales & $\mathbf{N}$ & Min. & Max. & $\overline{\mathbf{x}}$ & $\mathbf{S}$ \\
\hline Individual Innovation Scale & 199 & 38.88 & 46.00 & 43.01 & 1.40 \\
\hline Emotional Intelligence Scale & 199 & 1.00 & 5.00 & 4.05 & .86 \\
Organizational Behavior Scale & 199 & 1.42 & 5.00 & 3.76 & .72 \\
\hline
\end{tabular}

The average score of the participants in the Individual Innovation Scale $(\bar{x}=43.01)$, Emotional Intelligence Scale $(\overline{\mathrm{x}}=4.05)$ and Organizational Behavior Scale $(\overline{\mathrm{x}}=3.76)$ was showed in Table 1.

Table 2. Examination of the relationship between variables by Pearson Product-Moment Correlation

\begin{tabular}{|l|l|l|l|}
\hline & IS & EI & OB \\
\hline IS & 1 & & \\
\hline EI & $.61^{* *}$ & 1 & \\
\hline OB & $.66^{* *}$ & $.65^{* *}$ & 1 \\
\hline
\end{tabular}

Note. IS: Individual Innovation; EI: Emotional Intelligence; OB: Organizational Behavior.

$\mathrm{p}<.01$.

Considering Table 2, a significant, positive and moderate relationship was determined between individual innovation (IS), emotional intelligence (EI) and organizational behavior (OB).

Table 3. Multiple regression analysis results on the prediction of organizational behavior

\begin{tabular}{|l|l|l|l|l|l|l|}
\hline \multicolumn{2}{|c|}{} & Standardize $\beta$ & Standad Error & Critical Rate & $\mathbf{P}$ & $\mathbf{R}^{2}$ \\
\hline \multirow{2}{*}{ Organizational Behavior } & Individual Innovation & .43 & .03 & 7.01 & $* * *$ & \\
\cline { 2 - 7 } & Emotional Intelligence & .38 & .05 & 6.27 & $* * *$ & \\
\hline
\end{tabular}

Note. $* * * \mathrm{p}<.001$.

When the analysis results were examined a statistically significant effect was determined on 
the relationship between individual innovation (IS) and emotional intelligence (EI) and organizational behavior $(\mathrm{OB}),\left(\beta_{1}=.43 ; \mathrm{p}<.001 ; \beta_{2}=.38 ; \mathrm{p}<.001\right)$. Considering the Squared Multiple Correlations $\left(\mathrm{R}^{2}\right)$ value seen in Table 3; It can be said that $53 \%$ of organizational behavior is explained by individual innovation and emotional intelligence characteristics.

\section{Discussion}

A total of 199 personnel, 77 females (38.7\%) and 122 males (61.3\%), participated voluntarily in this study, which aims to determine to what extent the individual innovation and emotional intelligence levels of the personnel of the General Directorate of Sports contribute to the levels of exhibiting positive organizational behavior.

According to the results of the analysis, it was determined that the individual innovation ( $\overline{\mathrm{x}}=$ 43.01) and emotional intelligence $(\overline{\mathrm{x}}=4.05)$ levels of the participants were high. It is seen that there are studies in the literature that support the research results (Güngör \& Kurtipek, 2020; K1lıçer \& Odabaş1, 2010; Kurtipek \& Güngör, 2019). According to this finding, it is possible to say that employees are open to different experiences and can lead new ideas by not resisting change and taking risks.

According to another finding, employees got a score above the average $(\overline{\mathrm{x}}=3.76)$ from the organizational behavior scale. According to this finding, it is possible to state that behaviors that will guide a wide variety of positive outcomes about the organization are exhibited. Because there are many positive issues in the field of organizational behavior such as motivation, job design, conflict, locus of control, negotiation, power, leadership, communication, organizational culture, job satisfaction, organizational commitment and organizational change that can contribute to organizational success (Coşkun \& Tabak, 2017; Kaçay, Güngör, Yenel, \& Soyer, 2020; Robbins \& Judge, 2012; Uğur, 2021).

In addition, a significant, positive and moderate relationship was determined between the three variables (individual innovation, emotional intelligence, and positive organizational behavior). Kivrak (2018) found a significant and positive relationship between emotional intelligence and individual innovation in his study. He also emphasized that emotional intelligence is effective in overcoming difficulties, which contributes to exhibiting innovative behavior and enabling employees to reveal their creativity more easily.

Emotional intelligence in the literature; There are also studies on the relationship between variables such as life success (Baron, 2001), interpersonal relationships (Fitness, 2001), critical thinking disposition (Çelik \& Güngör, 2020) and work stress (Nikolaou \& Tsaousis, 2002; Slaski \& Cartwright, 2002). Accordingly, having a high level of emotional intelligence brings along the ability to easily cope with stressful situations, to shape social relationships in the right direction, and to be successful in life in general.

Employees with a high level of emotional intelligence are optimistic, they can find ways to cope with problems more easily by associating them with their previous experiences, they can take a more active position in human relations, as their ability to understand the emotions, thoughts and feelings of the other party through gestures, facial expressions and tones of 
voice, they can take a more active position by thinking about the positive results to reach a goal. they can motivate themselves, they are aware of the reasons for their own emotional states, they are skilled in generating new ideas and they can leave positive effects in their environment. Considering all these effects of emotional intelligence, it is possible that the levels of individual innovation and organizational behavior are high.

In organizations with high emotional intelligence, it is mentioned that there is an increase in performance, effective communication, high motivation and an efficient working environment (Doğan \& Demiral, 2007). According to the multiple regression analysis, it was determined that individual innovation and emotional intelligence explained organizational behavior by $53 \%$. From this point of view, it can be stated that individual innovation levels and emotional intelligence status have a serious importance in the development of organizational behavior characteristics of individuals. As a result, in order to contribute to exhibiting positive organizational behaviors, an organizational climate can be created where innovation, different ideas and emotional intelligence are supported, and where cooperation and interaction are intense.

\section{References}

Baron, D. (2001). Theories of strategic nonmarket participation: Majority-Rule and executive institutions. Journal of Economics and Management Strategy, 10, 7-45. https://doi.org/ 10.1111/j.1430-9134.2001.00047.x

Baysal, T. (2016). Türkiye’de kamu yöneticilerinin yetiştirilmesi, sorunlar ve çözüm önerileri. Akademik Yaklaşımlar Dergisi, 7(1), 186-213.

Bharadwaj, S., \& Menon, A. (2000). Making innovation happen in organizations: Individual creativity mechanisms, organizational creativity mechanisms or both? Journal of Product Innovation Management, 17(6), 424-434. https://doi.org/10.1111/1540-5885.1760424

Chan, D. W. (2004). Perceived emotional intelligence and self-efficacy among Chinese secondary school teachers in Hong Kong. Personality and Individual Differences, 36, 1781-1795. https://doi.org/10.1016/j.paid.2003.07.007

Chan, D. W. (2006). Emotional intelligence and components of burnout among Chinese secondary school teachers in Hong Kong. Teaching and Teacher Education, 22, 1042-1054. https://doi.org/10.1016/j.tate.2006.04.005

Coşkun, H., \& Tabak, A. (2017). Örgütsel davranış çalıştığımızda aslında ne çalışıyoruz? Türkiye'de yapılan lisansüstü tezler üzerinden bir değerlendirme. İş ve İnsan Dergisi, 4(2), 101-111. https://doi.org/10.18394/iid.297985

Çelik, O. B., \& Güngör, N. B. (2020). A structural model of the relationships between the emotional intelligence and the critical thinking disposition in physical education and sports teacher candidates. International Journal of Exercise Psychology, 2(1), 10-20.

Damanpour, F., \& Aravind, D. (2011). Managerial innovation: Conceptions, processes, and antecedents. Management and Organization Review, 8(2), 423-454. https://doi.org/10.1111/ 
j.1740-8784.2011.00233.x

Devloo, T., Anseel, F., Beuckelaer. A. D., \& Salanova. M. (2014). Keep the fire burning: Reciprocal gains of basic need satisfaction, intrinsic motivation and innovative work behaviour. European Journal of Work and Organizational Psychology, 24(4), 1-14. https://doi.org/10.1080/1359432X.2014.931326

Doğan, S., \& Demiral, Ö. (2007). Kurumların başarısında duygusal zekânın rolü ve önemi. Celal Bayar Üniversitesi İ.I.B.F. Manisa Yönetim ve Ekonomi Dergisi, 14(1), 209-230.

Fitness, J. (2001). Emotional intelligence and intimate relationships. In J. Ciarrochi, J. P. Forgas, \& J. D. Mayer (Eds.), Emotional intelligence in every day life: A scientific inquiry (pp. 98-112). Philadelphia, PA: Psychology press.

Güngör, N. B., \& Kurtipek, S. (2020). Examining the effect of individual innovation level of students of sports sciences faculty on digital literacy with structural equation model. Journal of Human Sciences, 17(2), 756-767. https://doi.org/10.14687/jhs.v17i2.6021

Hirst, G., Van Knippenberg, D., \& Zhou, J. (2009). A cross-level perspective on employee creativity: Goal orientation, team learning behavior, and individual creativity. Academy of Management Journal, 52(2), 280-293. https://doi.org/10.5465/amj.2009.37308035

Hurt, H. T., Joseph, K., \& Cook, C. D. (1977). Scales for the measurement of innovativeness. Human Communication Research, 4, 58-65. https://doi.org/10.1111/j.1468-2958.1977.tb00 597.x

Kaçay, Z., \& Soyer, F., (2020). İş yeri yılmazlı̆̆ının yordayıcıları örgütsel güven, lider-üye etkileşimi ve iş yeri maneviyatı. LAP LAMBERT Academic Publishing.

Kaçay, Z., Güngör, N. B., Yenel, F., \& Soyer, F. (2020). The Effect of Work Engagement and Mindfulness on Organizational Behavior. Journal of Educational Issues, 6(2), 478-492. https://doi.org/10.5296/jei.v6i2.17975

Kılıçer, K., \& Odabaşı, H. F. (2010). Bireysel yenilikçilik ölçeği (BYÖ): Türkçeye uyarlama, geçerlik ve güvenirlik çalışması. Hacettepe Üniversitesi Ĕgitim Fakültesi Dergisi, 38, 150-164.

Kurtipek, S., \& Güngör, N. B. (2019). Individual innovation: A research on sports manager candidates. Journal of Education and Learning, 8(1), 264-271. https://doi.org/10.5539/ jel.v8n1p264

Luthans, F. S. M., Norman, B. J., Avolio, B. J. \& Avey, J. B. (2008). The mediating role of psychological capital in the supportive organizational climate-employee performance relationship. Journal of Organizational Behavior, 29, 219-238. https://doi.org/10.1002/ job.507

Luthans, F., Avolio, B. J., Avey, J. B., \& Norman, S. M. (2007). Positive psychological capital: Measurement and relationship with performance and satisfaction. Personnel Psychology, 60(3), 541-572. https://doi.org/10.1111/j.1744-6570.2007.00083.x 


\section{Macrothink

Mayer, J. D., Salovey, P., \& Caruso, D. R. (2004). Emotional intelligence: Theory, findings and implications. Psychological Inquiry, 15(3), 197-215. https://doi.org/10.1207/s15327965 pli1503_02

Mumcuoğlu, Ö. (2002). Bar-on duygusal zekâ testi’nin Türkçe dilsel eşdeğerlik, güvenirlik ve geçerlik çalışması (Yüksek Lisans Tezi, Marmara Üniversitesi Eğitim Bilimleri Enstitüsü, İstanbul).

Nikolaou, I., \& Tsaousis, I. (2002). Emotional intelligence in the workplace: Exploring its effects on occupational stress and organizational commitment. International Journal of Organizational Analysis, 10, 327-342. https://doi.org/10.1108/eb028956

Robbins, S. P., \& Judge, T. (2012). Essentials of organizational behavior. Boston: Pearson.

Salovey, P., Caruso, D. R., \& Sitarenios, G. (2001). Emotional intelligence as a standard intelligence. Emotion, 1(3), 232-242. https://doi.org/10.1037/1528-3542.1.3.232

Shin, S. J., \& Zhou, J. (2003). Transformational leadership, conservation, and creativity: Evidence from Korea. Academy of Management Journal, 46(6), 703-714. https://doi.org/ $10.2307 / 30040662$

Slaski, M., \& Cartwright, S. (2002). Health, performance and emotional intelligence: An exploratory study of retail managers. Stress and Health, 18, 63-68. https://doi.org/ 10.1002/smi.926

Tabachnick, B. G., \& Fidell, L. S. (2013). Using multivariate statistics (International edition). Pearson.

Tuncer, F. H. (2018). Duygusal zekânın çalışanların bireysel yenilikçiliği üzerine etkisi: Teknoloji şirketleri üzerine bir araştırma (Yüksek Lisans Tezi, İstanbul Üniversitesi Sosyal Bilimler Enstitüsü, İstanbul).

Uğur, O. A. (2021). Examination of locus of control levels of university students staying in credit and dormitories institution. Turkish Journal of Sport and Exercise, 23(1), 67-74. https://doi.org/10.15314/tsed.896128

Yıldız, N. O., \& Bostancı, T. G. (2016). Bireylerin iş yaşamlarına ilişkin motivasyon düzeylerine dağcılık sporunun etkisi. Beden Eğitimi ve Spor Bilimleri Dergisi, 18(3), 65-77.

Yıldız, N. O., \& Çiftçi S. (2021). Spor işletmelerinde hedef belirleme süreci: Dalış okulları örneği. Ankara, Gazi Kitabevi.

Zhou, J., \& George, J. M. (2001). When job dissatisfaction leads to creativity: Encouraging the expression of voice. Academy of Management Journal, 44(4), 682-696. https://doi.org/ $10.2307 / 3069410$ 


\section{Copyright Disclaimer}

Copyright for this article is retained by the author(s), with first publication rights granted to the journal.

This is an open-access article distributed under the terms and conditions of the Creative Commons Attribution license (http://creativecommons.org/licenses/by/3.0/). 